\title{
Mapping and historical reconstruction of the great Mexican 22 June 1932 tsunami
}

\author{
N. Corona ${ }^{1}$ and M. T. Ramírez-Herrera ${ }^{1,2}$ \\ ${ }^{1}$ Centro de Investigaciones en Geografía Ambiental, Universidad Nacional Autónoma de México, Campus Morelia, México \\ ${ }^{2}$ Laboratorio de Geofísica Ambiental, Universidad Nacional Autónoma de México, Campus Morelia, México
}

Correspondence to: N. Corona (ncorona@pmip.unam.mx), M. T. Ramírez-Herrera (mtramirez@ciga.unam.mx)

Received: 4 November 2011 - Revised: 25 March 2012 - Accepted: 26 March 2012 - Published: 9 May 2012

\begin{abstract}
At 07:00 h (UTC-6) on 22 June 1932, a $M_{\mathrm{s}}=6.9$ earthquake shocked the coasts of Colima and Jalisco. Five minutes later a tsunami arrived at the coast. It almost completely destroyed the town of Cuyutlán, Colima, causing the deaths of 50 people and leaving about 1200 injured. In this study, newspaper reports and technical reports are reviewed, as well as survivors' testimonials. The physical characteristics (mean sea level at the time, time of arrival, sea retreat, and inundation distribution) and the tsunami effects (number of victims, injuries, affected buildings) have been reconstructed and mapped. The interpretation of historical data allowed us to determine the intensity of the tsunami and to reveal the tsunamigenic source. This study emphasizes the relevance of historical analysis, including survivor's testimonies, in the reconstruction of tsunamis that lack instrumental data. The results of this study are relevant to paleotsunami studies and tsunami related hazard planning.
\end{abstract}

\section{Introduction}

Natural phenomena have caused devastating damage throughout human history. Among the most catastrophic phenomena are tsunamis, e.g. the 26 December 2004 Indian Ocean tsunami which lead to the deaths of about 250000 people and damage exceeding 10 billion dollars, and the recent 11 March 2011 Tohoku, Japan tsunami and earthquake which caused over 24000 deaths and missing people (Mimura et al., 2011). A list of 11939 records of natural disasters shows that 51 correspond to tsunamis (EM-DAT, 2011). The Indian Ocean tsunami of 2004 however killed over 226000 people (CRED, 2005). This disaster led to the progress of new research aimed at better understanding of the origin and behaviour of tsunamis (Kanamori, 2006; Stein, 2006; Satake and Atwater, 2007; Lagos and Cisternas, 2008). It demonstrated starkly the high cost of ignoring the past and history of territories that have been affected by tsunamis (Lagos and Cisternas, 2008). Historical and geological studies can provide information that may help understand the occurrence and recurrence of large earthquakes and tsunamis (Orfanogiannaki and Papadopoulos, 2007; Satake and Atwater, 2007; Yanagisawa et al., 2007).

Most tsunamis are caused by earthquakes produced in subduction zones (Stein, 2006; Kanamori, 2006; Satake and Atwater, 2007; Stein and Okal, 2007). All countries located on the Pacific Ocean are susceptible to tsunamis associated with seismic activity of the Pacific Ring of Fire (Goff, 2011). The Pacific Mexican Coast (PMC) has a record of 70 tsunamis in the period of 1732 to 2011 (HTDB/WLD, 2011). The most destructive tsunamis were those of 16 November 1925 in $\mathrm{Zi}$ hutanejo and 22 June 1932 in Cuyutlán (Sánchez and Farreras, 1993).

The study of natural phenomena with instrumental data is a modern practice that started only in the second half of eighteenth century (e.g. Barriendos et al., 2003; Llasat et al., 2005). Before this, information was based on qualitative pieces of information (Fliri, 1998). The incorporation of historical research techniques into the natural hazards studies has proven to be a useful tool, as there are many types of data sources that can be included: paintings, photographs, prints, legends, letters, government reports, etc. (Wang and Zhang, 1988; Pfister, 1999; Naulet et al., 2001; Wagner and Suda, 2004). These sources of information can be subjective, but the subjectivity can be resolved through critical evaluation of the information (Pfister, 1999). 
Numerous authors have proposed that historical analysis is an invaluable tool for hazard studies (Ambraseys, 1979, 1995; Ambraseys and Adams, 1996; Glade et al., 2001; Calcaterra et al., 2003; Barnikel, 2004; Lübken and Mauch, 2011). Historical data has been used and complemented by other proxy data in the field to study floods (e.g. Barriendos et al., 2003; Benito and Thorndycraft, 2004; Llasat et al., 2005; Seidel et al., 2009; Balasch et al., 2010), landslides (e.g. Sigurdsson et al., 1985), storms and hurricanes (e.g. Pfister, 1999; Kates et al., 2006; Ribera et al., 2011), earthquakes (e.g. Ambraseys and Finkel, 1990; Glade et al., 2001; Fréchet et al., 2008) and tsunamis (e.g. Gianfreda et al., 2001; Pelinovsky et al., 2001; Strunz et al., 2011). Historical data have also been used in event reconstruction (e.g. Gianluca, 2005; Guidoboni, 2008; Seidel et al., 2009; Balasch et al., 2010) and modeling (e.g. Pelinovsky et al., 2001; Walsh et al., 2003).

Given the importance of recognizing the history of tsunamis in coastal territories and the role of historical data in the construction of this knowledge, this study focuses on historical data collection, and on interpreting and mapping the physical characteristics and the effects of the great 1932 Mexican tsunami, an event that has no instrumental records and that caused significant damage to the Colima coast. The aim of this study is to map the physical characteristics and effects of the 1932 Cuyutlán tsunami at the local scale, and to determine the tsunami intensity using ethnographic, geographic and modeling techniques.

The study provides new data on the spatial distribution and effects of the 1932 tsunami on the Cuyutlán, Mexico coast. This is the first study that assigns an intensity value to a tsunami in Mexico. The results provide useful information for tsunami hazard evaluation and planning, as well as for palaeotsunami research. The tsunami intensity allows the estimation of parameters, such as the magnitude of the inundation and water flow rate as it enters the coast, which are useful elements in vulnerability assessment and tsunami risk. Finally, the study demonstrates that the use of historical written data, the testimony of the population and the use of mapping techniques (georeferencing of descriptive elements and GIS modelling) are an important sources of information and tools in describing natural phenomena and disasters that lack instrumental data.

\subsection{Tsunami history in the study area}

The study area is located in the Jalisco-Colima area, along the Pacific Coast of Mexico. This region is influenced by tectonic activity related to the subduction of the Cocos and Rivera plates under the North American plate along the Mesoamerican Trench (Singh et al., 1981, 1985; Nixon, 1982; Eissler and McNally, 1984; Luhr et al., 1985; RamírezHerrera et al., 1999, 2011).

Historically, the Cuyutlán coast has a record of six tsunamis: 3, 18, 22 and 29 June 1932; 19 September 1985, and 9 October 1995 (NGDC, 2011; HTDB/WLD, 2011). However, based on the interpretation of historical data by NGDC (2011) and HTDB/WLD (2011), it was inferred that at least 27 tsunamis reached the Cuyutlán coast from 1875 to 2011 (Fig. 1). Historical data indicate that another tsunami inundated the salinas of San Pantaleon (currently El Real town) and penetrated about $400 \mathrm{~m}$ inland on 13 November 1816 (Oseguera, 1967).

On 3 June 1932 the greatest earthquake ever registered in Mexico occurred in this region $\left(M_{\mathrm{s}}=8.2\right)$, followed by aftershocks on 18 June $\left(M_{\mathrm{S}}=7.8\right)$ and 22 June $\left(M_{\mathrm{S}}=6.9\right)$ (Singh et al., 1981, 1985; Astiz and Kanamori, 1984). These events produced tsunamis (Cumming, 1933; Singh et al., 1998; NGDC, 2011; HTDB/WLD, 2011). The largest tsunami of these series was the 22 June (Cumming, 1933; Sánchez and Farreras, 1993; Okal and Borrero, 2011). However, the answer to the source location and mechanism of the 22 June tsunami is still unsolved (Singh et al., 1998). Two hypotheses have been proposed to solve this problem: (1) a seismic source (Singh et al., 1998; NGDC, 2011; Okal and Borrero, 2011), and (2) a submarine landslide (Cumming, 1933).

The 22 June tsunami affected $75 \mathrm{~km}$ of the coast of Colima, between $19.06^{\circ} \mathrm{N}$ and $104.31^{\circ} \mathrm{W}$ near Manzanillo Bay, and $18.68^{\circ} \mathrm{N}, 103.74^{\circ} \mathrm{W}$ near Boca de Apiza (NGDC, 2011). This study is focused on the Cuyutlán coast, where most of the damage occurred along a segment about $6 \mathrm{~km}$ long (Fig. 2). The coastal morphology is characterized by sandy beaches and sand dunes parallel to the coastline, rising to heights between 6 and $15 \mathrm{~m}$ a.s.l. A strip of coastal plain extends inland and Laguna de Cuyutlán is bordered on the northeast by fringes of mangrove swamp and saltpans (salinas). Cuyutlán is a tourist town and has a tradition of salt extraction. It has a population of 926 inhabitants and 845 households (INEGI, 2010).

\section{Methods}

This study applied ethnographical and geographical approaches (Fig. 3). Ethnographic techniques used included content analysis and interviews. During the first phase, i.e. data collection, two main sources of information were obtained: written documents and eyewitness testimony. Written documents included journal articles, books, technical reports, catalogues, newspapers and pictures that were reviewed using a content analysis technique (Murchison, 2010; Secor, 2010). The focus was on the identification of informant names, tsunami data and key topics (Table 1). Based on this information, a list of topics was used as a guide in the construction of a semi-structured interview format (Denscombe, 2003). Also, a list of potential interviewees was created. Sampling was carried out using the snowball format in a field survey (Walliman, 2006; Murchison, 2010).

The selection of informants was limited to eyewitnesses and descendants of survivors. Informants included an 


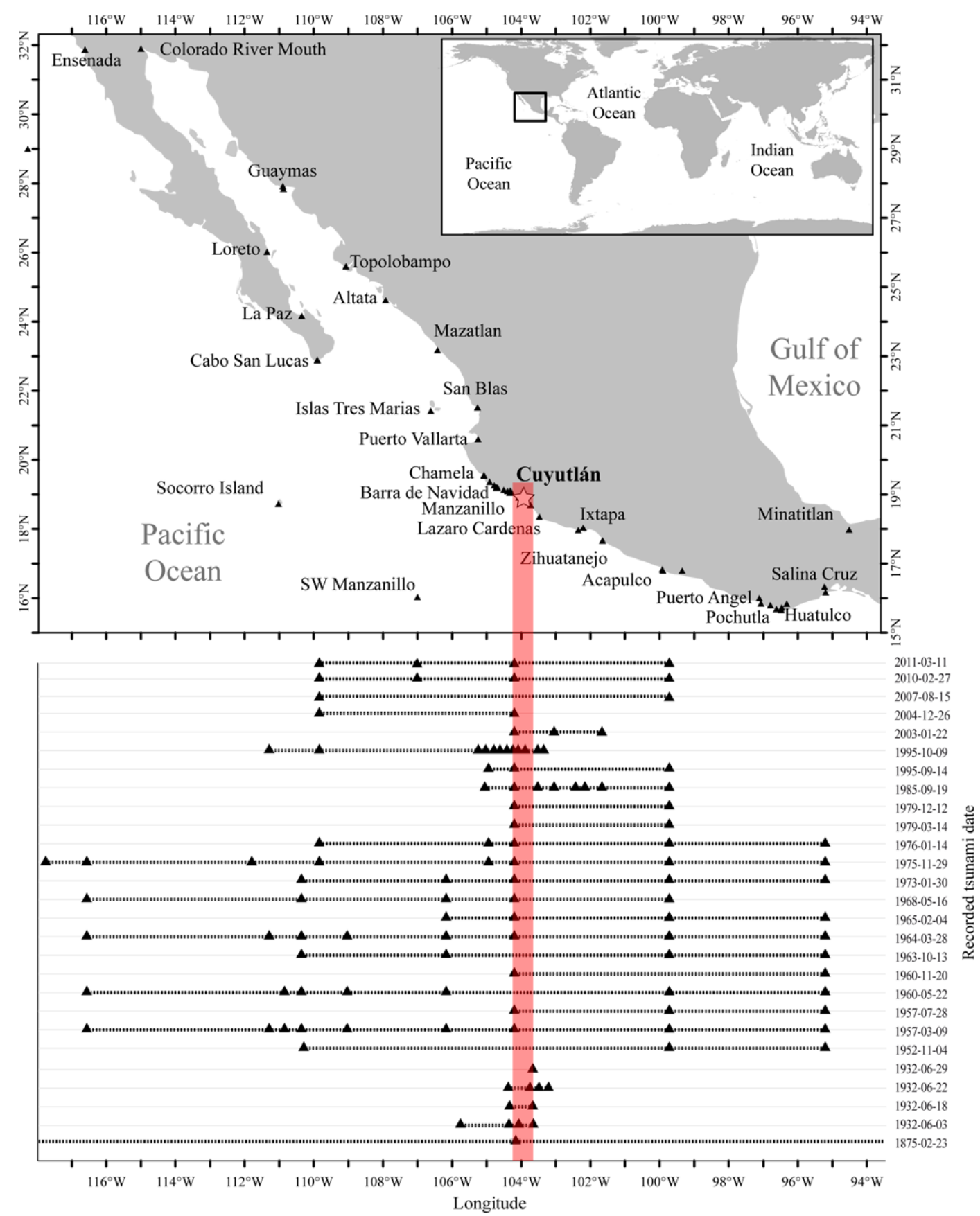

Fig. 1. Coastline affected by historical tsunamis that have reached Cuyutlán. Black triangles, location that reported tsunamis (HTDB/WLD, 2011; NGDC, 2011) from 1875-2011; dash lines, probable tsunami affected longitude on each date, but without record on corresponding locations. Red vertical band, study area, Cuyutlán coast.

eyewitness, Pachita Gaspar (92 yr), children of eyewitnesses: Ramón Cortez (70 yr), Vidal Vázquez Mojarro (76 yr), María de Jesús Morales (50yr), Ignacio de la Madrid (78 yr) and wife (76 yr), José Solórzano (52 yr), and the chronicler of the city Miguel Chávez Michel (62 yr).

One of the most important references in this study is the technical report produced by Cumming (1933), who visited the affected area a few days after the tsunami impact. This document provides a significant number of descriptive elements not mentioned in other sources, which underlines the importance of post-tsunami surveys.

Once the written data and the eyewitness testimonies had been collected, a content analysis was applied in order to interpret the whole disaster scenario. The data was analysed 
Table 1. Data source references and derived interview topics.

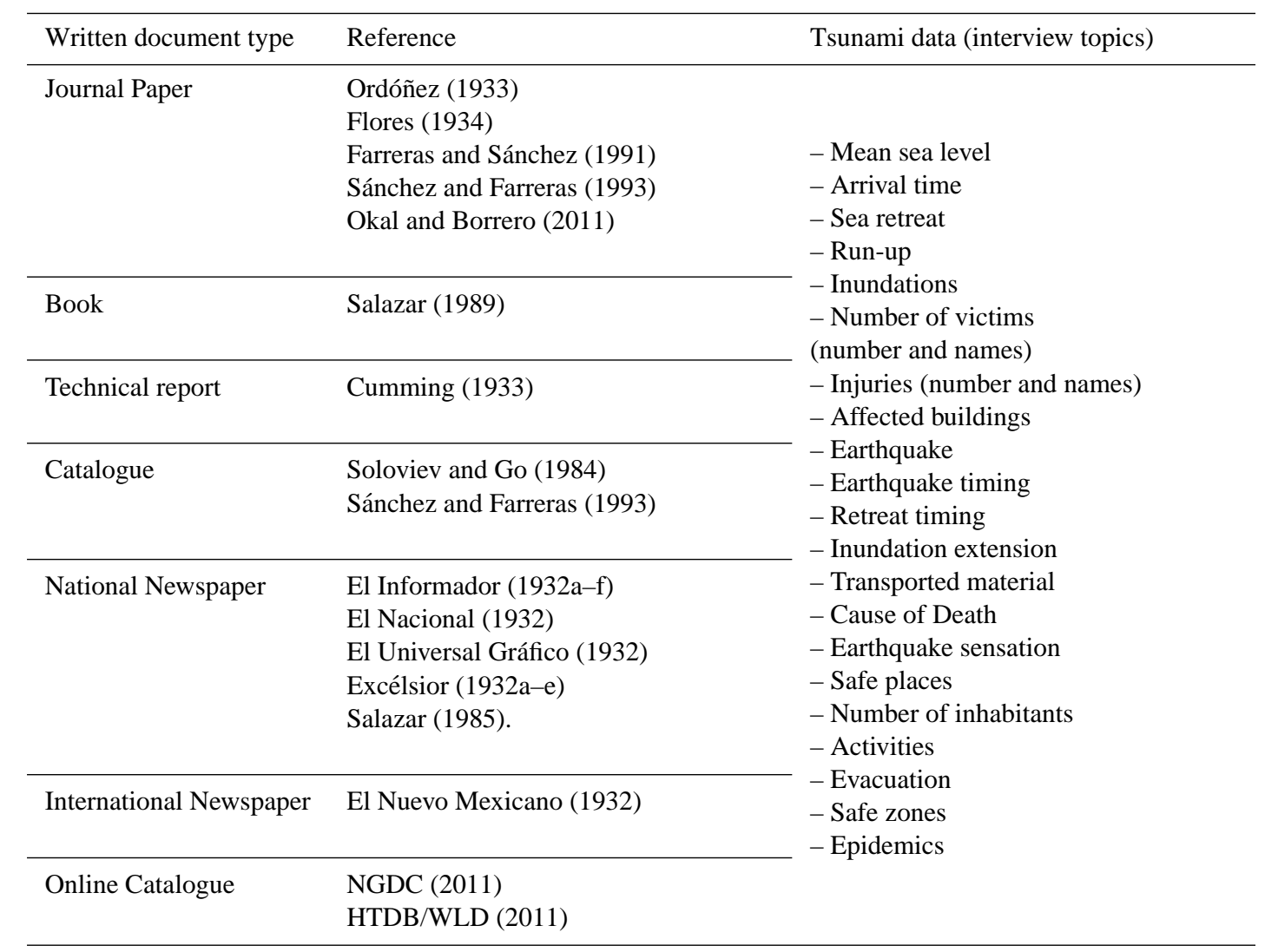
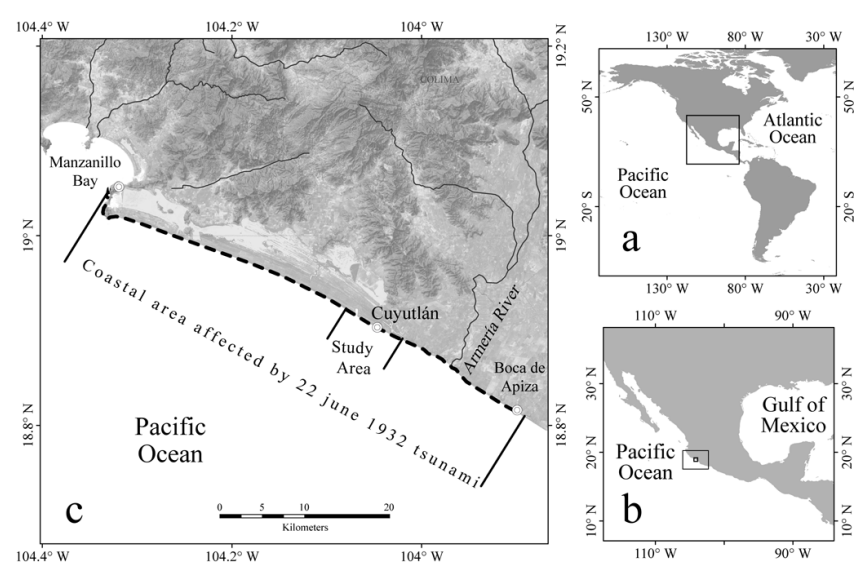

Fig. 2. Study area location. (a) Regional setting, (b) Mexico, and (c) study area. Dash line shows the tsunami area affected by the June 22, 1932 tsunami (NGDC, 2011).

to generate a complete tsunami description, divided in two groups: effects and physical properties of the tsunami. The effects were classified according to the scheme proposed by UNESCO-IOC (2006), which refers to direct and indirect impacts.
To determine the tsunami intensity level, data was analysed using the Papadopoulos and Imamura (2001) intensity scale (Table 2).

A Digital Elevation Model (DEM) and a 1932 planimetric map of the town were developed to map effects and physical tsunami properties. For the DEM generation a topographic survey was carried out using a theodolite Keuffel and Esser model S50. Data was collected through an orthogonal equidistant dot net using the Polar Coordinates Method, while the Graphical Method (Casanova, 2002) was used to draw the topographic contour lines. For de DEM generation the Surface Delaunay Triangulation Method was used (Liseikin, 2010). The planimetric map was drawn to define the location of each building in the town of Cuyutlán in 1932. The reconstruction of this pre-tsunami stage was done by digitising (Gregory and Ell, 2007) polygons over a panchromatic Worldview 2 (WV2) at $0.6 \mathrm{~m}$ spatial resolution (acquisition date April 2011). The identification and location (mapping) of each building, the tsunami effects and its physical properties on the base map was done by means of the Geospatial Visual Correlation Method (GVCM), using a base map (topo-planimetric map), written data, pictures, eyewitness descriptions and field survey (Kovalerchuk, 2004). Additionally, a geomorphological interpretation (Goff et al., 


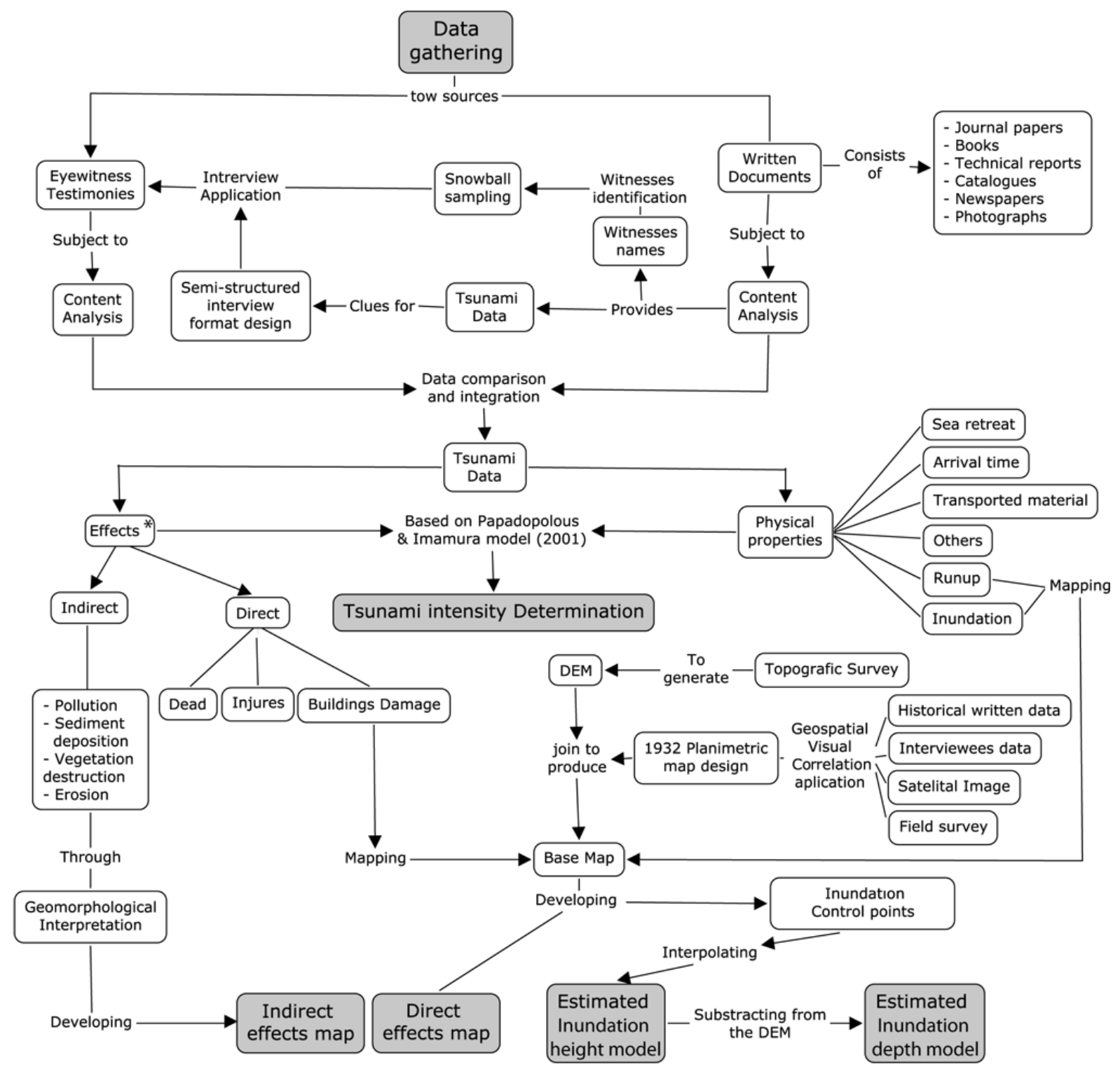

Fig. 3. Flow methodology chart. *Note: the tsunami effects were classified according to the scheme proposed by UNESCO-IOC (2006).

Table 2. Characteristics of a VIII intensity tsunami according to Papadopolous and Imamura (2001).

\begin{tabular}{ll}
\hline Intensity scale & VIII. Heavily damaging \\
\hline Effects on humans & All people escaped to higher ground, a few were washed away. \\
\hline Effects on objects & $\begin{array}{l}\text { Most of the small vessels were damaged, much area washed away. Few large vessels } \\
\text { were moved ashore or crashed into each other. Big objects were drifted away. Erosion } \\
\text { and littering in the beach. Extensive flooding. Slight damage in tsunami control forest, } \\
\text { stop drifts. Many aquaculture rafts washed away, few partially damaged. }\end{array}$ \\
\hline Damage to buildings & $\begin{array}{l}\text { Most wooden structures were washed away or demolished. Damage of grade } 2 \text { in a few } \\
\text { masonry buildings. Most RC buildings sustain damage, in a few damage of grade } 1 \text { and } \\
\text { flooding is observed }\end{array}$ \\
\hline
\end{tabular}

Note: recorded data of the 22 June 1932 Cuyutlán tsunami is highlighted. 


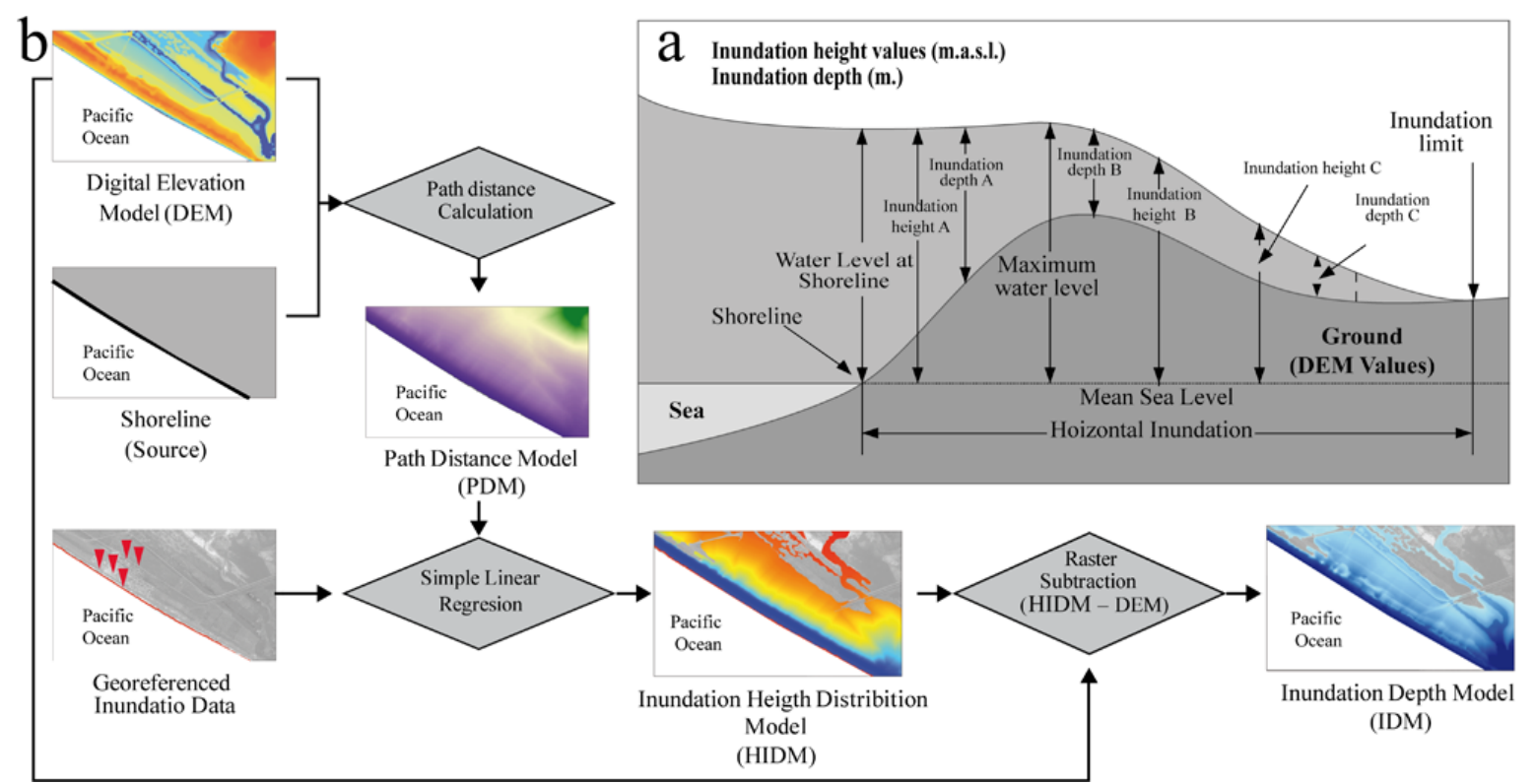

Fig. 4. Inundation height and Inundation depth interpolation method, where (a) shows the tsunami profile (Levin and Nosov, 2009) adapted for modelling purpose, and (b) the flow diagram for the inundations modelling.

2007, 2009) of the DEM model and image WV2 were applied to map the tsunami's indirect effects.

An empirical and simple approach was applied for a maximum inundation height and inundation depth modelling. The main objective was to create a hypothetical continuous distribution model of the inundation height and depth over the affected area using the few available recorded data and topographic survey data. Using water marks left by the tsunami, observed on photographs and recorded by locals recounts, we developed a simple model of the inundation distribution, though a simple equation that reflects this inundation distribution pattern. Inundation height distribution was mapped interpolating the values of the georeferenced tsunami information about water level at shoreline, maximum water level and recorded inundation water marks heights (as points with height values). In this study inundation height was interpreted and represented as the shoreline motion inland, and represents water levels measured in meters above sea level (Pedersen, 2008). The schematic tsunami profile in Fig. 4 shows the water height motion applied for modelling purpose. The Simple Linear Regression Method was used to find the best-fit equation (O'Sullivan and Unwin, 2003). A path distance model (PDM) (Zhan et al., 1993) was used as independent variable and a value for water mark heights, taken from the mapped tsunami physical properties, was used as dependent variable. The PDM was created considering that inundation height distribution is a direct function of the distance travelled by the tsunami water column. The PDM measures the distance (meters) from the shoreline inland in perpendicular to the shoreline (PDM origin), taking into account the diagonal pixel distance and the accumulative effects of the topographic stage (DEM), interpreted as a simple friction factor. The inundation depth map was shaped using a simple raster arithmetic method, subtracting the values of the maximum inundation height model from the DEM model (Fig. 4).

\section{Results}

\subsection{Pre-tsunami review of town characteristics}

\subsubsection{Society and economy}

Cuyutlán's main economic activities in the early 30's consisted of cultivation and extraction of coconut products, salt extraction, an activity that dates back to the late sixteenth century, and tourism. Salt extraction, cultivation and coconut product activities were located in Cuyutlán in the same places as they are today, except for the fact that some areas southwest of the town, near Palo Verde Ranch (Reyes, 2004), have been cleared of such activities, as a turtle-nesting reserve ("El Tortugario") has been created there.

In the early 30's the number of tourists visiting Cuyutlán was about 3000 people, most of whom visited during Holy Week in April (Salazar, 1989). Cuyutlán's Salters' Cooperative claimed to have employed up to 2000 people at that time, in harvest periods between March and June (Reyes, 2004). Agricultural activity occurred throughout the year, and local farmers were in charge of the crops. 


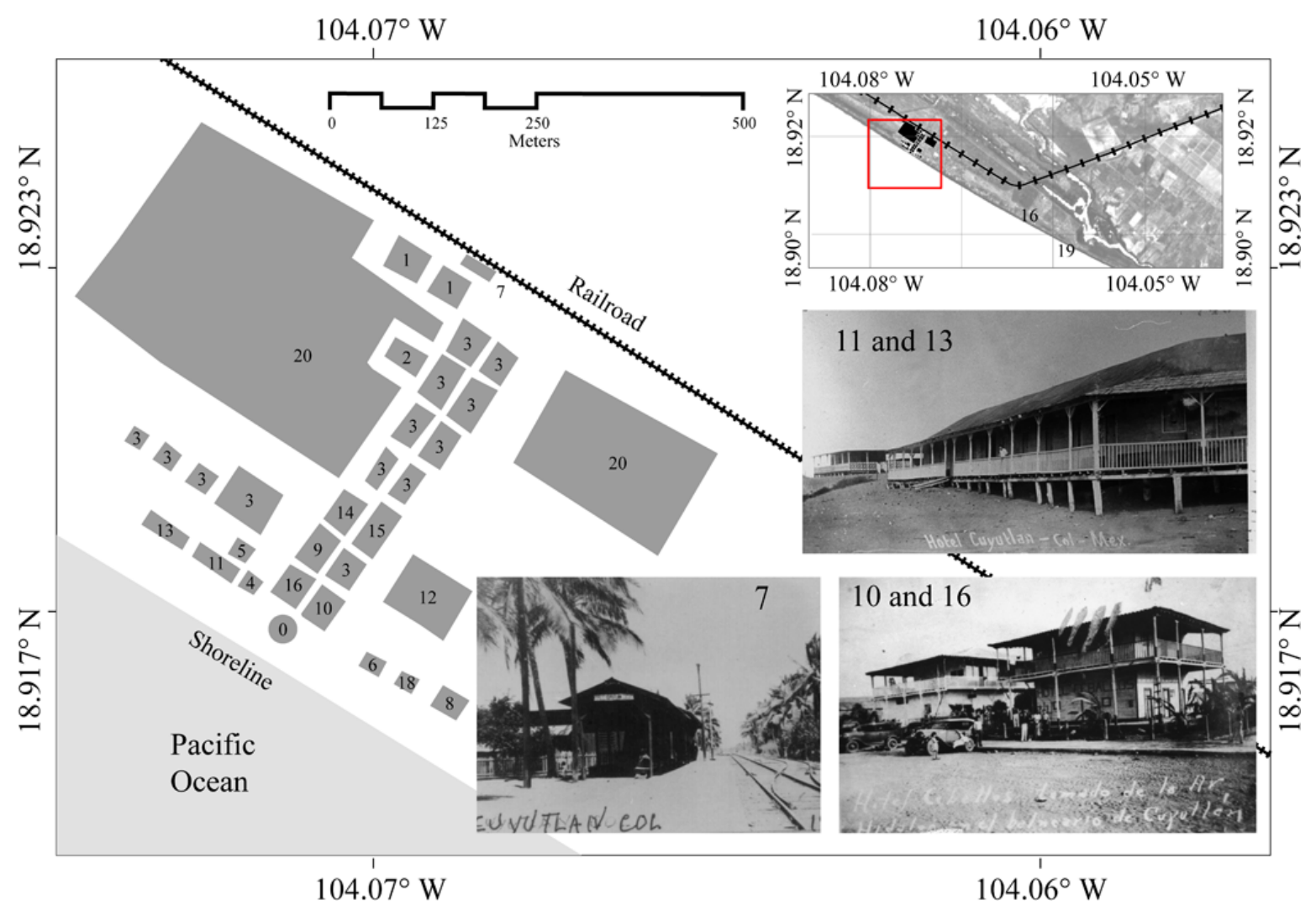

Fig. 5. Planimetric map of Cuyutlán in 1932. (0) Old stone roundabout, (1) Salt warehouse, (2) Little church, (3) private little houses, (4) Aguayos's Chalet, (5) Solorzano's Chalet, (6) Wattles, (7) Train station, (8-9) Hotels nameless, (10) Hotel Ceballos, (11) Hotel Cuyutlán, (12) Hotel Madrid, (13) Hotel Palacios, (14) Hotel Santa Cruz \#1, (15) Hotel Santa Cruz \#2, (16) Hotel Zapotlan, (17) Ordeña Anguiano, (18) Hostal, (19) Palo Verde Ranch and (20) Housing zone.

\subsubsection{Buildings}

Small structures of wood and palm leaf ("palapas") were spread along the beach. Close to the beach, where the terrain is gentle, hotels and larger private buildings were located. These buildings were made of wood and had stronger structures than the huts and buildings for residential use (Salazar, 1989; Hernández, 2009). Other hotels were located on the dune slopes; the largest was The Hotel Madrid, which was located on the top of the dunes, about $10 \mathrm{~m}$ a.s.l. Most of the houses were located on the strip of coastal plain, and built of shingles, palm and mud (Gaspar, 2010; Mojarro, 2010; De la Madrid, 2010). It is estimated that in total there were 80 to 100 homes with these characteristics (Salazar, 1989) (Fig. 5).

The main transport infrastructure was the railroad that connected Cuyutlán with the city of Colima, and with Manzanillo Bay. The railroad station, built of wood, was located in the same place as today, about $500 \mathrm{~m}$ from the coastline. Around the train station there were houses, built of wood and mud that belonged to the Salters'Cooperative workers. Finally, a small chapel built of wood was located on the coastal plain near the residential area (Salazar, 1989; Gaspar, 2010).

\subsection{Tsunami physical properties}

\subsubsection{Source and arrival time}

Data explaining the source mechanism of the great 1932 tsunami have not yet been defined (Singh et al., 1998). Two hypotheses have been proposed to explain the origin of the 22 June event: (1) a tsunamigenic earthquake (Singh et al., 1998; NGDC, 2011; Okal and Borrero, 2011), or (2) an underwater landslide (Cumming, 1933). Cumming (1933) points out that the palm trees and infrastructure washed away by the tsunami at Cuyutlán were oriented to the northwest. This suggests that the tsunami came from the opposite, i.e. southeast direction. However the earthquake epicentre of 22 June 1932 was located northwest of the town (Cumming, 1933; Cruz and Wyss, 1983). Based on historical data analysis, the photographs and observations by Cumming (1933), we infer that the tsunami source was located somewhere southeast of Cuyutlán, a location that coincides with a submarine canyon in front of the mouth of the Armería River (Fig. 6). The time lapse between the earthquake and the arrival of the wave was five minutes (Salazar, 1985; Gaspar, 2010). 


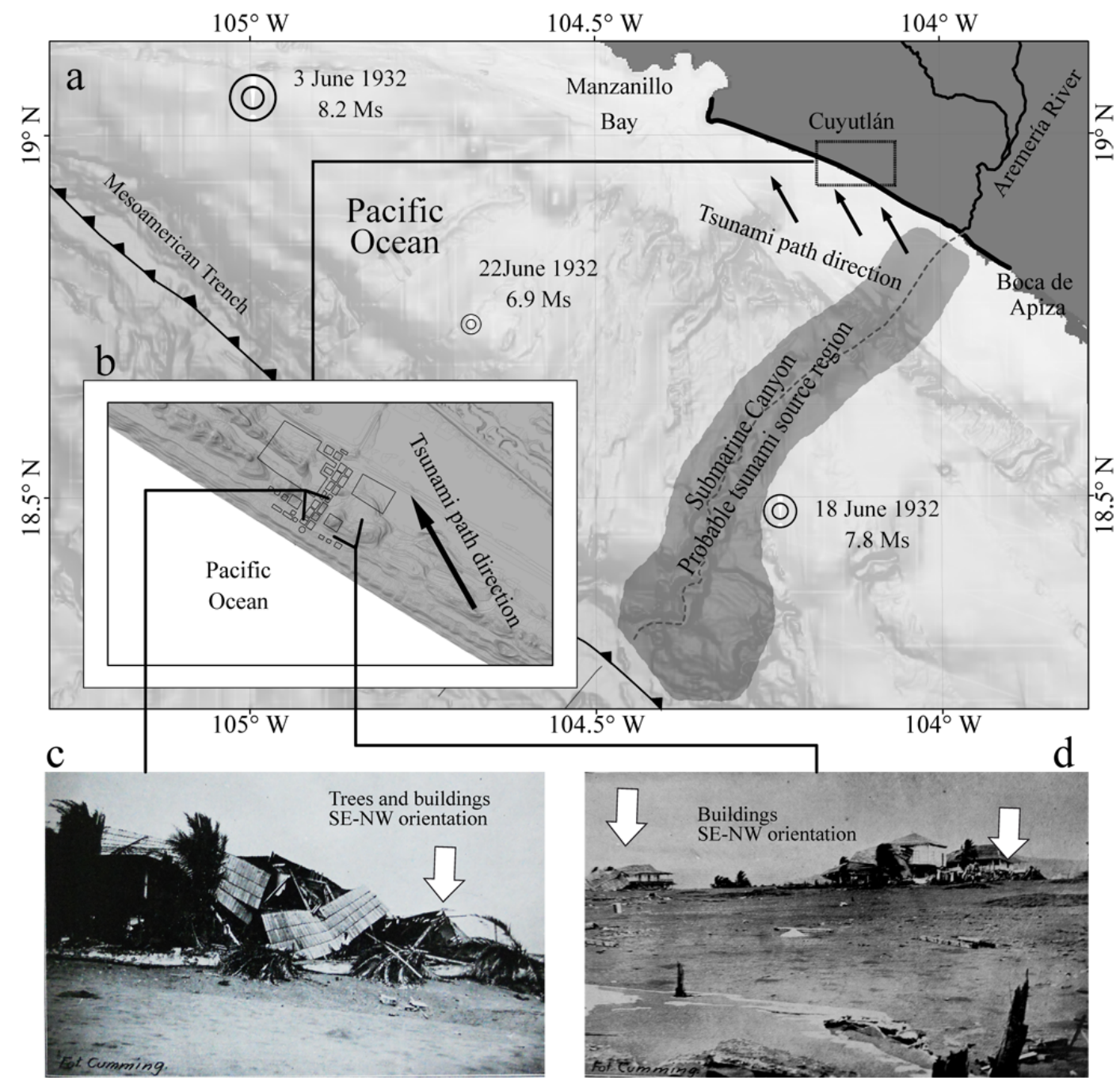

Fig. 6. Probable location of the 22 June 1932 tsunami source and path direction. (a) main earthquake epicentres of June 1932 (Cumming, 1933; Cruz and Wyss, 1983; SSN, 2010), dark grey transparent polygon shows the submarine canyon in front of the mouth of the Armería river, where the probable source of the 22 June 1932 tsunami was located, dark arrows show the probable SE-NW path direction of the tsunami; (b) main affected zone at Cuyutlán; (c and d) pictures of the some trees and buildings demolished and washed away by the tsunami, shown with white arrows (Cumming, 1933).

\subsubsection{Mean sea level and sea retreat}

A relative sea level change was reported on 3 June as a result of the $M_{\mathrm{S}}=8.2$ earthquake (Cumming, 1933). The testimony of the mayor of Cuyutlán at the time confirms this apparent change: "The sea level was higher after the earthquake... the stone roundabout was not so close to the sea (before the event), and it was at a distance of approximately 50 meters". Cumming (1933) also suggests a probable drop (subsidence) of the coast by one meter. On the other hand, the calculated tide by a tide gauge at 07:00 h (UTC-6) on 22 June was at $-329 \mathrm{~mm}$ below m.s.l. (MAR, 2010). Considering this data, we infer that sea level in Cuyutlán at the time of the tsunami was most probably close to $671 \mathrm{~mm}$ a.m.s.l. on 22 June. Prior to the 22 June tsunami, the sea retreated ap- proximately $200 \mathrm{~m}$ from the coastline (Excélsior, 1932a). It is inferred that the sea retreat occurred in ranges between 150 and $300 \mathrm{~m}$ from the Cuyutlán coastline. Sea retreat was reported as only about $9 \mathrm{~m}$ (30 feet) to the northwest, in the Manzanillo Bay (El Informador, 1932a).

\subsubsection{Inundation height}

The maximum height reached by the water column, $2 \mathrm{~m}$, was recorded at the Hotel Madrid located $10 \mathrm{~m}$ a.m.s.l. (El Informador, 1932c; Salazar, 1989; De La Madrid, 2010). It is estimated that the maximum tsunami inundation height and the maximum water level, $12 \mathrm{~m}$, was reached at this point (Fig. 7). Another watermark was identified along the main avenue on the coastal plain, $450 \mathrm{~m}$ from the shoreline and at 

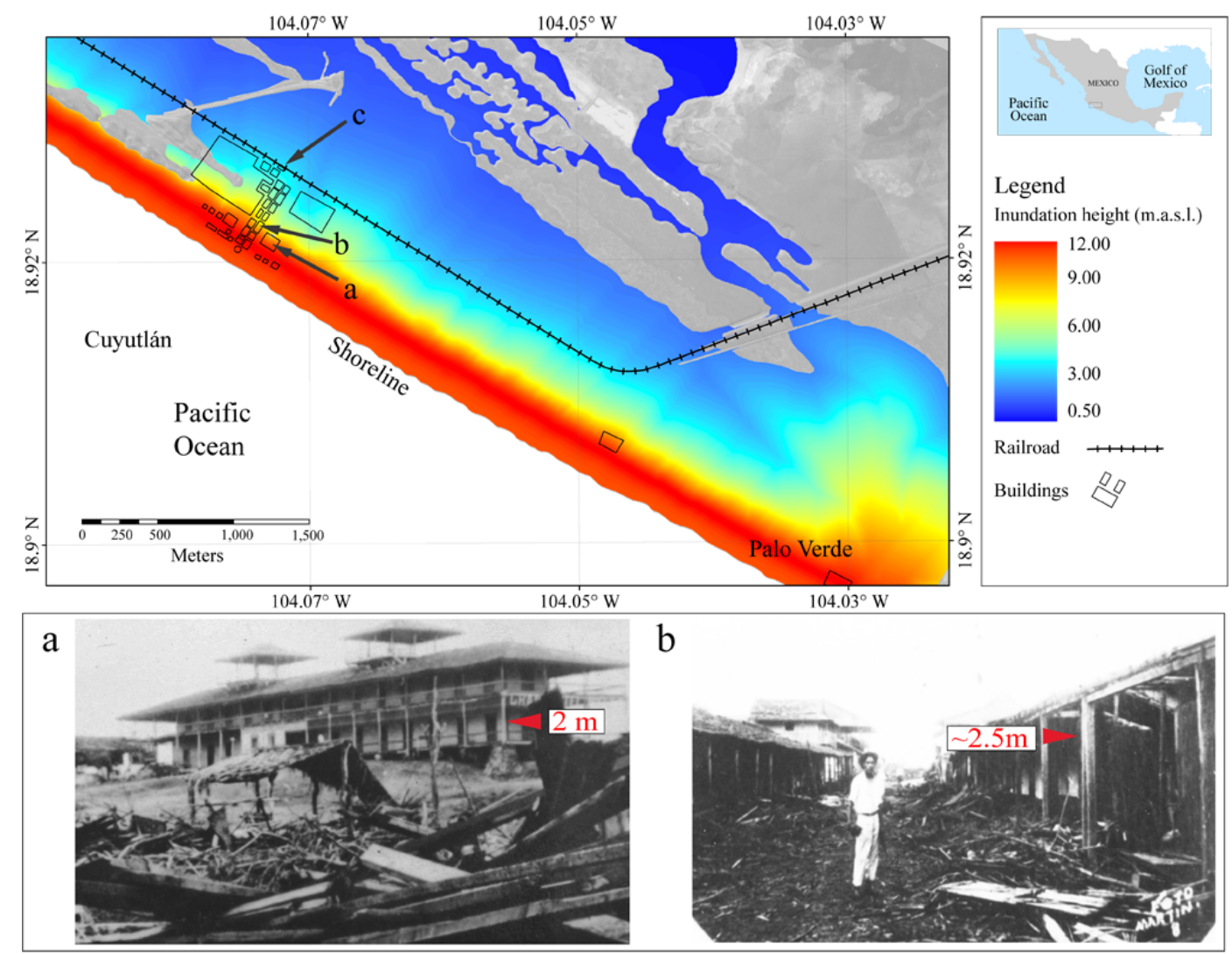

Fig. 7. Inundation height distribution model of the 22 June 1932 tsunami; (a) Madrid Hotel; (b) Main Street (El Informador, 1932c); (c) Train station.

$5 \mathrm{~m}$ a.m.s.l., reaching about $2.5 \mathrm{~m}$. Therefore the inundation height was inferred to be about $7.5 \mathrm{~m}$. At the train station, located at $3.5 \mathrm{~m}$ a.m.s.l. and $720 \mathrm{~m}$ from the shoreline, according to the description by Ms. Pachita Gaspar: “... when we climbed like cats onto the train cars, the height of water in the railway station was approximately $1.5 \mathrm{~m}$ high... "(Gaspar, 2010), indicating that the tsunami height reached $5 \mathrm{~m}$ (Fig. 7).

Identified water level at shoreline, maximum water level, and inundation height points were sampled and correlated with the path distance model for the interpolation modelling (Table 3). The correlation coefficient resulting from the bestfit equation (Eqs. 1 and 2) was 0.999 , where " $y$ " is the interpolated inundation height (in $m$ a.m.s.l.) value and " $x$ " is the PDM value (in $\mathrm{m}$ ),

$y^{-1}=a+b x^{1.5}+c x^{2}$.

In addition to Eq. (1),

$y=\frac{1}{a+b x^{1.5}+c x^{2}}$,

in addition to Eqs. (1) and (2),

$a=0.0833$ $b=-1.45 \times 10-6$

$c=4.33 \times 10-8$.

Substituting the values of " $x$ " with the values of the path distance model a inundation height tsunami distribution model was generated (Fig. 7).

\subsubsection{Inundation depth}

The maximum inundation depth reached during the 22 June tsunami was $12 \mathrm{~m}$ on the shoreline (water level at shoreline). At the Hotel Madrid, located on the top of a sand dune $10 \mathrm{~m}$ a.m.s.l., inundation depth reached $2 \mathrm{~m}$, and 2 to $3 \mathrm{~m}$ toward the sand dunes, $450 \mathrm{~m}$ inland on the main street in Cuyutlan (Farreras and Sánchez, 1991). While further inland, $720 \mathrm{~m}$ at the train station, inundation depth reached $1.5 \mathrm{~m}$ (Gaspar, 2010). The inundation depths varied across the study area because of the local relief and the height of the dunes. Southeast of the town, lower sand dunes gradually lose height close to the Palo Verde salt flats (Reyes, 2004), where the mouth of the estuary is located. These relief characteristics produced variations in the extent of inland inundation, that at minimum reached $500 \mathrm{~m}$ from the shoreline around the train station (Salazar, 1989) to a maximum of 
Table 3. Control points list and corresponding values of digital terrain models.

\begin{tabular}{lllll}
\hline $\begin{array}{l}\text { Id control } \\
\text { point }\end{array}$ & $\begin{array}{l}\text { PDM* } \\
\text { Values }(\mathrm{m})\end{array}$ & \multicolumn{3}{c}{ Control Points } \\
\cline { 3 - 5 } & & $\begin{array}{l}\text { Inundation } \\
\text { depth (m) }\end{array}$ & $\begin{array}{l}\text { DEM** } \\
(\mathrm{m} \text { a.m.s.l.) }\end{array}$ & $\begin{array}{l}\text { Inundation height } \\
\text { values (m a.m.s.l.) }\end{array}$ \\
\hline Shoreline & 0.00 & 12.00 & 0.00 & $12.00^{* * *}$ \\
Hotel Madrid & 1394.88 & 2 & 10 & $12.00^{* * * *}$ \\
Main Street & 1559.93 & 2.50 & 5 & 7.5 \\
Train Station & 3000.00 & 1.50 & 3.5 & 5 \\
\hline
\end{tabular}

* Path Distance Model; ** Digital Elevation Model; ***Water level at shoreline; **** Maximum water level

about $3000 \mathrm{~m}$ (El Nuevo Mexicano, 1932) from the shoreline in the east and southeast of the town (Fig. 8).

Cuyutlán was inundated in two minutes up to a distance of about $450 \mathrm{~m}$ from the shoreline. Southeast of Cuyutlán, $2.5 \mathrm{~km}$ from the shoreline, close to a section of the railroad, the area was inundated in $3 \mathrm{~min}$ (El Nacional, 1932; Excélsior, 1932d). Considering these two parameters, it is estimated that the mean water flow velocity was 5 to $5.5 \mathrm{~m} \mathrm{~s}^{-1}$, which is consistent with average velocities observed by other tsunamis (e.g. Camfield, 1994; Nott, 1997; Titov and Synolakis, 1997; EERI, 2011)

The area drained in about three hours. Drainage went in two directions, one heading southeast through the beach, and the other to the sea through the estuary, southeast from Boca de Apiza (Farreras and Sánchez, 1991). This drainage most probably went through the Armería River, located $11 \mathrm{~km}$ southeast of Cuyutlán, because the estuary and Cuyutlán lagoon are connected by the Armería River.

An inundation depth model was generated from the inundation height values minus the heights values on the DEM (Fig. 8).

\subsubsection{Materials transported by the tsunami}

Different materials were transported by the tsunami, including sands, remains of buildings, trees and coconut palms (Salazar, 1985, 1989; Gaspar, 2010). Fish were swept from the ocean and deposited around the town as far as the railroad tracks, as De la Madrid indicated: “...my dad came from the well ... coming down the railroad and there were plenty of fish..." (De la Madrid, 2010). The tsunami transported domestic animals and larger livestock to a lesser extent. Among other things, a truck was dragged inland (Salazar, 1985).

\subsubsection{Others}

Many eyewitness and written documents indicate that people heard thunder, a sound that was followed by the retreat of the sea and the arrival of the water at the coast (Salazar, 1985; Chávez, 2010; De La Madrid, 2010; Gaspar, 2010; Mojarro, 2010).
Data also refers to the effects of previous earthquakes in June 1932, mainly damage produced by the 3 and 18 June events. Cumming (1933) states that buildings were not damaged by the earthquake of 22nd. Eyewitness and written documents also indicate that motion produced by the 22 June earthquake was not felt or perceived by residents (Salazar, 1985; De la Madrid, 2010; Gaspar, 2010; Mojarro, 2010).

\subsubsection{Direct effects}

The death toll was 50 people (El Informador, 1932c). The vast majority of deaths occurred among children (Salazar, 1985). Initially it was believed that there were more victims, but as Vidal Mojarro Vázquez said: “...there were people who we thought had been drowned, but they went far away... Those persons appeared later ... " (Mojarro, 2010). The number of injured was 67, the main causes for this were the impact of construction debris dragged by the wall of water (El Informador, 1932a). The number of people living in Cuyutlán who were affected by the tsunami was 1181 (Excélsior, 1932c; INEGI, 2010).

Tourist infrastructure located between the beach and sand dunes was the most damaged. Of the seven hotels in town, six were destroyed: Hotel Ceballos, Santa Cruz \# 1, Santa Cruz \# 2, Hotel Palacio, Hotel Zapotlan and El Gran Hotel (Fig. 9). Four of the largest chalets built of timber were destroyed: Chavez's House, Aguayo's Chalet, and Solórzano Chalet (Excélsior, 1932d; Salazar, 1989).

In general, all baths made of palm wood (locally named "enramada") near the beach were destroyed. Furthermore, all the smaller buildings, made mostly of shingle, mud, and palm with palm leaf roofs, were completely destroyed (El Universal Gráfico, 1932; Excélsior, 1932c, d; Salazar, 1989). In total, approximately 80 homes were destroyed (Fig. 9)

The paved streets of Cuyutlán were completely stripped and rocks were transported as far as the railway. Railroad tracks were partially buried by sand deposits and vegetation. A one-kilometer stretch of railroad track was blocked by debris, trees, fish and trash (El Informador, 1932b; El Universal Gráfico, 1932; Excélsior, 1932d, e). 


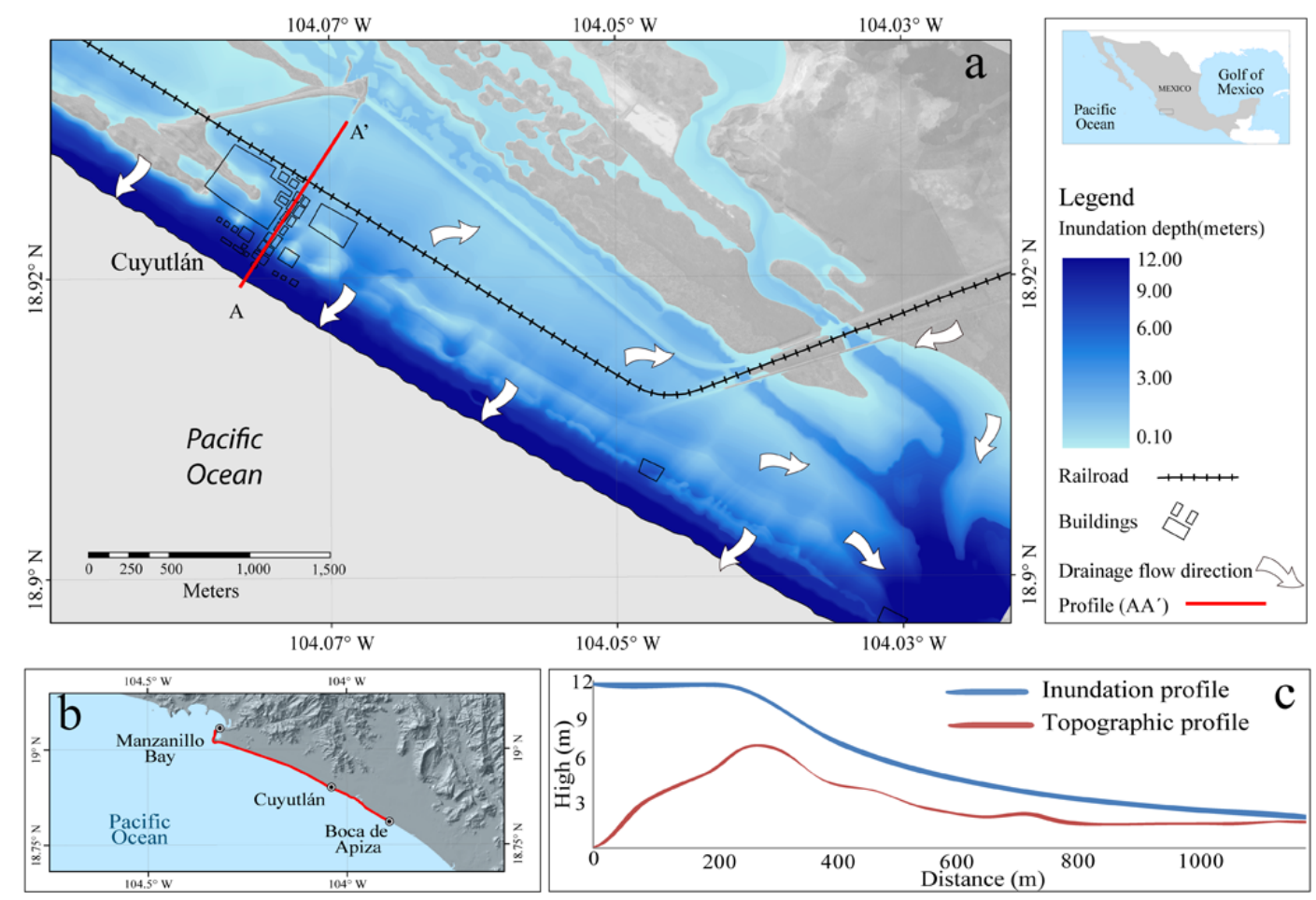

Fig. 8. Inundation depth model of the 22 June 1932 tsunami. (a) Map of the estimated inundation depth model, (b) the 22 June 1932 tsunami extension along the Pacific Coast (NGDC, 2011). (c) Topographic and inundation profile (A-A') across of the Cuyutlán town. White arrows represent an indicative probable drainage flow direction.

It was not possible to calculate the amount and type of material goods that were lost. However, data collected indicate that the main economic activities at the time were tourism and salt industry. The tourism infrastructure was very badly damaged; with the exception of the Madrid, all the hotels were completely destroyed or so seriously damaged that they could not be restored. The salt industry was also affected because 2000 tons of salt that were stored in the salt warehouse were lost and only 300 tons were recovered (El Informador, 1932d, e; De La Madrid, 2010; Mojarro, 2010).

\subsubsection{Indirect effects}

One indirect effect produced by the tsunami was the pollution of the Palo Verde Ranch Salinas (saltflats). One interviewee noted that the salinas were buried by sand after the tsunami, leaving them useless for salt extraction (Mojarro, 2010). At Palo Verde, as described by Reyes (2004): "In the past the estuary was connected with the ocean in its southeastern corner, through the Palo Verde marsh; that connection was lost in 1932 when the tsunami filled and covered the estuary with sand" (Fig. 10).

Tsunami erosion was most evident in the sand dunes (El Informador, 1932f; Salazar, 1985; Chávez, 2010; Mojarro, 2010). Comparison of eyewitness descriptions with current geomorphological features shows that sand dune segments were eroded. The sand and material brought by the tsunami overwash was deposited in lower areas inland, corresponding to the coastal plains and the outer edge of the estuary and salt marsh areas (El Informador, 1932a; Excélsior, 1932b; Salazar, 1985, 1989; Chávez, 2010; De la Madrid, 2010). In the tsunami backwash, remains of buildings, trees and trash were deposited widely over the sandy beach (Fig. 10).

\subsection{Tsunami intensity}

To determine the 22 June tsunami intensity the Papadopoulos and Imamura (2001) scale was used. This scale is a qualitative assessment of the tsunami effects on the people, objects, and buildings. Applying the characteristics of each intensity level in the Papadopoulos and Imamura scale it was found that the great 1932 tsunami had an intensity level of VIII. Table 2 shows the list of characteristics of a VIII tsunami intensity level.

\section{Discussion and conclusions}

The reconstruction of the 22 June tsunami through a historical analysis allowed us to determine that on 22 June 1932, sea level was higher than normal due to coastal subsidence produced by the $M_{\mathrm{S}}=8.2,3$ June event; a sea retreat occurred before the tsunami arrival at the Cuyutlán coast. Inundation heights were estimated to be up to $12 \mathrm{~m}$, and tsunami 

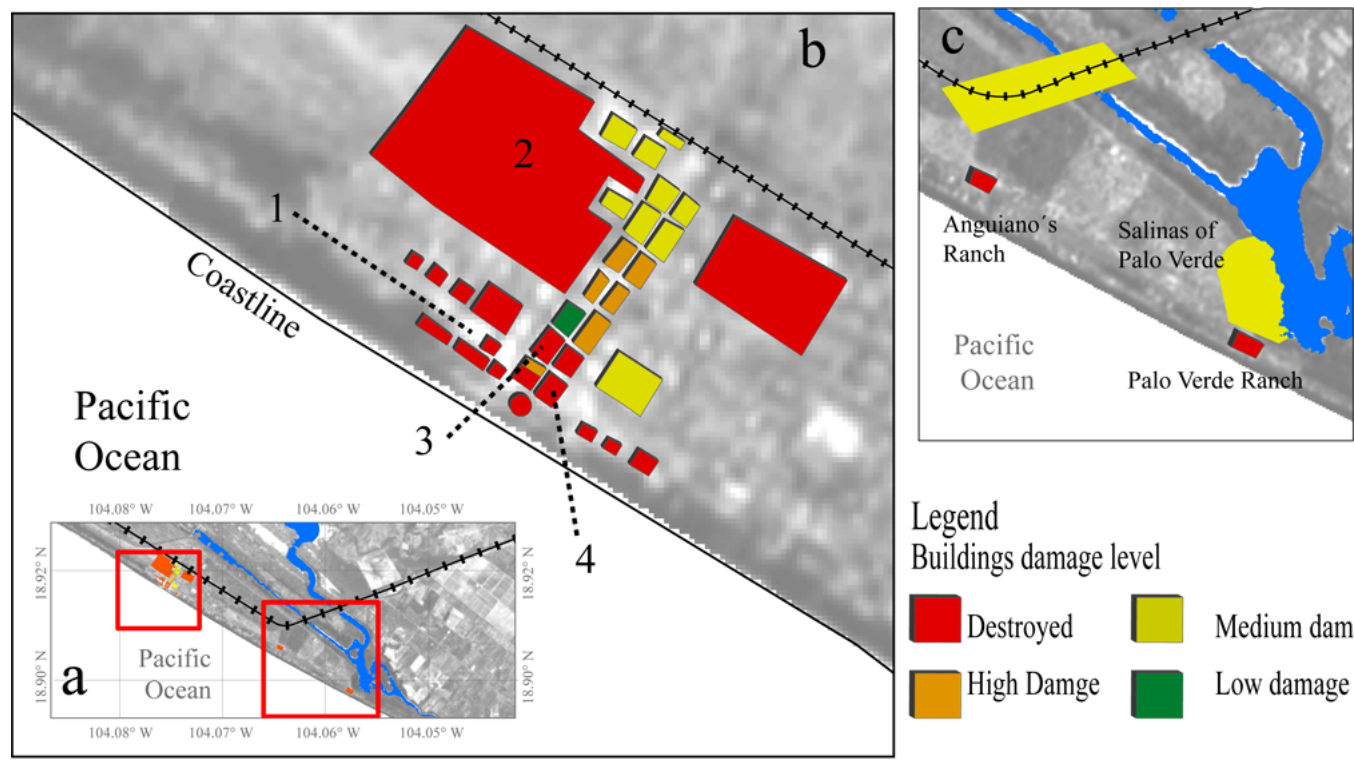

Legend

Buildings damage level

1

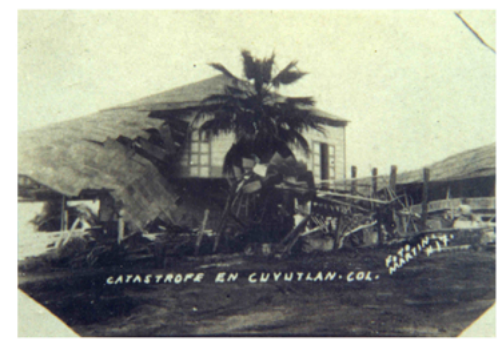

3

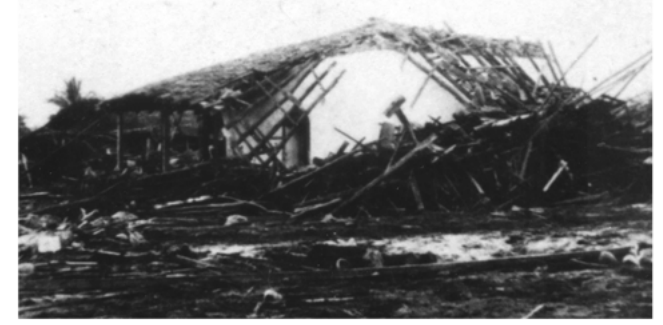

2

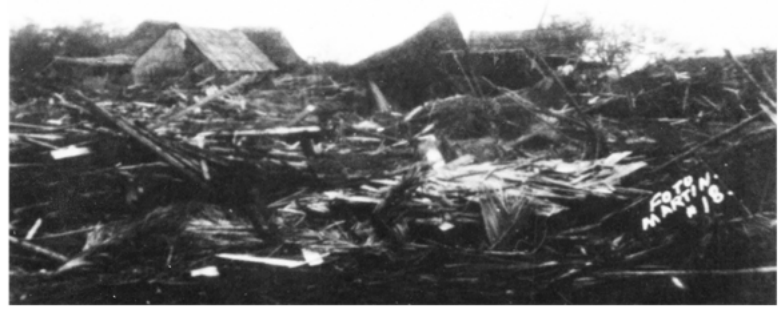

4

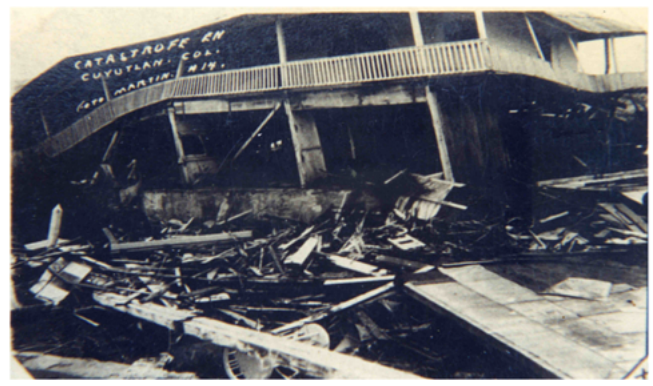

Fig. 9. Direct effects and building damage level map. (a) Cuyutlán, Colima map. Squares show the most affected zones, (b) most affected zone at Cuyutlán and damage level on each building. (1) Aguayo's Chalet, (2) view to destroyed houses, (3) Hotel Santa Cruz \#1 (El Informador 1932c), and (4) Hotel Ceballos. (c) The settlements of Anguino's Ranch and Palo Verde Ranch completely destroyed, railroad section with medium damage level and medium damaged Salinas of Palo Verde.

inundation extension varied according to the local topography. The water level was estimated from photographs with an error of $\pm 10 \mathrm{~cm}$. Modelling was based on four well identified control points (Table 3), and the selection of the best fit equation allowed to built a continuous map of the distribution of inundation levels. The tsunami inundated the study area $450-2000 \mathrm{~m}$ inland within $2-3 \mathrm{~min}$ and water drained out in about $3 \mathrm{~h}$. We realize the simplicity of the proposed inundation distribution model that shows a distribution pattern based only on the available data. This model does not include the topographic conditions present before the tsunami event nor does it include morphologic changes on the coast after the event, merely because no detailed topographic data exists previous to the event. The proposed model does not pretend to substitute a complex hydrodynamic model, but to offer a simple model that allows to infer the inundation distribution on places and situations that lack the necessary data to run more complex models. The reconstruction of the tsunami physical characteristics made it possible to elucidate the source mechanism that generated it. Most probably an earthquake-triggered submarine landslide is the source mechanism, based on the fact that probably the 3 and 


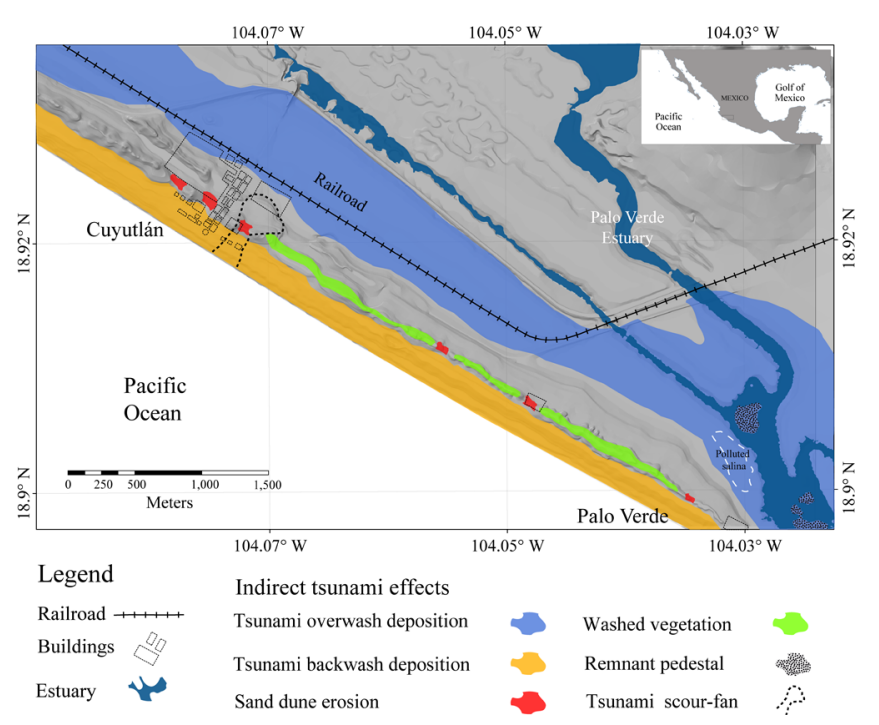

Fig. 10. Indirect tsunami effects map.

18 June earthquakes destabilized the sediments on the submarine canyon walls (Fig. 6), and the 22 June earthquake probably triggered their collapse. Besides, considering the tsunami direction indicated by Cumming (1933), it makes more sense that the tsunami source was at the submarine canyon. However, this statement requires further work to corroborate it. The 22 June tsunami characteristics fit a VIII tsunami intensity level (Papadopoulos and Imamura, 2001). We were able to determine the economic loss and damage in the local infrastructure, the number of deaths and injuries and changes on the landscape produced by the tsunami. Modelling of the inundation heights and inundation depth are two of the main elements in tsunami hazard assessment.

The gradual anthropogenic land use change produced after 1932 (e.g. coconut cultivation, new infrastructure and buildings) posed a difficulty in the geomorphologic interpretation of tsunami effects (Goff et al., 2008). Nevertheless, the interpretation and identification of some morphologic features produced by the 1932 tsunami was possible. Tsunami-scour fan associated with the overwash flow were identified close to the current main street (Goff et al., 2007, 2008, 2009). Broken dunes features formed by tsunami erosion were found in several segments of the beach ridges that run parallel to the beach front (Fig. 10). Likewise, probable remnant pedestals were located in the estuary at a distance of 400 to $850 \mathrm{~m}$ from the shoreline, behind the Palo Verde Ranch (Fig. 10). Other morphological features associated with the tsunami, such as hummoky topography, usually located landward on the overwash deposition zone (Goff et al., 2007), were not identified because of the post-1932 land changes. In a broad sense, the 1932 Cuyutlán tsunami fits with the description of a large event, with $10 \mathrm{~m}$ and greater inundation height (Goff et al., 2007).
Although the historical approach has proven its potential in the reconstruction of different kind of natural phenomena (e.g. Gianfreda et al., 2001; Glade et al., 2001; Pelinovsky et al., 2001; Kates et al., 2006; Ribera et al., 2011), the ethnographic approach is not enough when no written documents are available and when most eyewitness have died; if this is the case, then other techniques have to be applied. Clearly, the limitations on historical tsunami reconstruction relate to the availability of reports and eyewitness survival.

The importance of rescuing eyewitness testimonies and oral tradition, often forgotten, combined with document review and the use of GIS has proven to be a useful tool in interpreting the physical characteristics and behaviour of the great 1932 tsunami. This information is needed in hazard planning programmes, land use regulations, building codes, evacuation programmes and preparedness strategies.

Acknowledgements. N. Corona acknowledges CONACYT for a PhD scholarship. M. T. Ramírez-Herrera acknowledges research funds provided by PAPPIT UNAM grant IN123609 and SEPCONACYT grant No. 129456. Help, advice and logistical help came from L. M. Morales, P. Urquijo, Sedna Monter and GTT Imaging S.A de C.V. Photographs signed by "Martin" and used on Figs. 6 and 8 came from "El Gordo" (Resident of Armería) private collections. Proof-reading help came from M. Skutsch. We thank the editor Stefano Tinti, Josep Carles Balasch Solanes and an anonymous reviewer for valuable comments that help to improve this manuscript.

Edited by: S. Tinti

Reviewed by: J. C. Balasch Solanes

and another anonymous referee

\section{References}

Ambraseys, N. N.: A test case of historical seismicity: Is-fahan and Chahar Mahal, Iran, Geogr. J., 145, 56-71, 1979.

Ambraseys, N. N.: Magnitudes of Central American earthquakes 1898-1930, Geophys. J. Int., 121, 545-556, doi:10.1111/j.1365246X.1995.tb05732.x, 1995.

Ambraseys, N. N. and Adams, R. D.: Large-magnitude Central American earthquakes, 1898-1994, Geophys. J. Int., 127, 665692, doi:10.1111/j.1365-246X.1996.tb04046.x, 1996.

Ambraseys, N. N., and Finkel, C. F.: The Marmara Sea earthquake of 1509, Terra Nova, 2, 167-174, doi:10.1111/j.13653121.1990.tb00059.x, 1990.

Astiz, L. and Kanamori, H.: An earthquake doublet in Ometepec, Guerrero, Mexico, Phys. Earth Planet. Int., 34, 24-45, 1984.

Balasch, J. C., Ruiz-Bellet, J. L., Tuset, J., and Martín de Oliva, J.: Reconstruction of the 1874 Santa Tecla's rainstorm in Western Catalonia (NE Spain) from flood marks and historical accounts, Nat. Hazards Earth Syst. Sci., 10, 2317-2325, doi:10.5194/nhess-10-2317-2010, 2010.

Barnikel, F.: The value of historical documents for hazard zone mapping, Nat. Hazards Earth Syst. Sci., 4, 599-613, doi:10.5194/nhess-4-599-2004, 2004.

Barriendos, M., Coeur, D., Lang, M., Llasat, M. C., Naulet, R., Lemaitre, F., and Barrera, A.: Stationarity analysis of historical 
flood series in France and Spain (14th-20th centuries), Nat. Hazards Earth Syst. Sci., 3, 583-592, doi:10.5194/nhess-3-5832003, 2003.

Benito, G. and Thorndycraft, V. R. (Eds.): Systematic, Palaeoflood and Historical Data for the Improvement of Flood Risk Estimation, UE-CSIC, Madrid, 2004.

Calcaterra, D., Parise, M., and Palma, B.: Combining historical and geological data for the assessment of the landslide hazard: a case study from Campania, Italy, Nat. Hazards Earth Syst. Sci., 3, $3-$ 16, doi:10.5194/nhess-3-3-2003, 2003.

Camfield, F. E.: Tsunami effects on coastal structures, J. Coastal Res., 12, Special Issue, 177-187, 1994.

Casanova, L.: Topografía Plana, Taller de Publicaciones de Ingeniería-ULA, Mérdia, 2002.

Centre for Research on the Epidemiology of Disasters (CRED): available at: http://www.em-dat.net/figures2004.htm, access: 2 January 2011, 2005.

Chávez, M.: The day when the sea went out, interview conducted by Corona, N.: November 10, 2010, in Colima, Colima, 2010.

Cruz, G. and Wyss, M.: Large Earthquakes, mean sea level, and tsunamis along the Pacific Coast of Mexico and Central America, B. Seismol. Soc. Am., 73, 553-570, 1983.

Cumming, J. L.: Los terremotos de Junio de 1932 en los estados de Colima y Jalisco, Universidad de México, 31-32, 68-104, 1933.

De la Madrid, I.: The day when the sea went out, interview, conducted by Corona, N.: June 10, 2010, in Cuyutlán, Colima, 2010.

Denscombe, M.: The Good Research Guide: for small-scale social research projects, Open University Press, Maidenhead/Philadelphia, 2003.

Earthquake Engineering Research Institute (EERI): The Tohoku, Japan, Tsunami of March 11, 2011: Effects on Structures, Earthquake Engineering Research Institute, Special Earthquake Report, 1-14, available at: http://www.eqclearinghouse.org/2011-03-11-sendai/files/ 2011/03/Japan-Tohoku-report-tsunami-bldgs.pdf, 2011.

Eissler, H. K. and McNally K. C.: Seismicity and tectonics of the Rivera Plate and implications for the 1932 Jalisco, Mexico, earthquake, J. Geophys. Res., 86, 4520-4530, 1984.

El Informador: Cuyutlán a punto de desaparecer bajo las aguas del Océano Pacífico, El Informador, p. 1, p. 2, June 22, 1932, 1932 a.

El Informador: La catástrofe ocurrida anteayer en Cuyutlán no tiene precedente, p. 1, p. 2, June 24, 1932, 1932b.

El Informador: Gráficos del estado en que quedo el famoso balneario de Cuyutlán, Col., p. 1, p. 2, June 26, 1932, 1932c.

El Informador: Se perdió gran cantidad de sal, p. 7, June 26, 1932, $1932 d$.

El Informador: Han sido formidables los recientes terremotos, p. 4, June 28, 1932, 1932e.

El Informador: Las victimas de Cuyutlán arrojan un saldo de doce muertos y 67 heridos, p. 6, June 28, 1932, $1932 \mathrm{f}$.

El Nacional: Todo cuanto encontró a su paso arrasó furiosamente el mar, 1 pp., June 24, 1932, 1932.

El Nuevo Mexicano: Un testigo presencial describe las escenas crispantes-Total destrucción del balneario-niños ahogados flotan en charcos, p. 2, June 21, 1932, 1932 b.

El Universal Gráfico: En Cuyutlán no quedó piedra sobre piedra, p. 15, June 23, 1932, 1932.

EM-DAT: available at: http://www.emdat.be/result-disasterProfiles?disgroup=natural $\&$ period $=900 \% 242011 \&$ dis_type $=$
Earthquake+\%28seismic+activity\%29\&Submit=Display+

Disaster+Profile, access: 10 January 2011.

Excélsior: Una extensa zona marítima afectada por el sismo de ayer, p. 3, June 23, 1932, 1932a.

Excélsior: Cuyutlán arrasado por la invasión del océano: Gigantescas olas arrasaron las casas y la gente, p. 1, June 23, 1932, $1932 b$.

Excélsior: Dos veces más Cuyutlán barrido por las olas, p. 1, June 24, 1932, 1932c.

Excélsior: Mil doscientos huyen hacia Colima, Excélsior, p. 3, June 24, 1932, 1932d.

Excélsior: Tres Minutos Fueron Suficientes Para Arrasar el Balneario de Cuyutlán, p. 1, p. 2, p. 3, June 25, 1932, 1932e.

Farreras, S. and Sánchez, J. A.: The tsunami threat on the Mexican West Coast: A historical analysis and recomendations for hazard mitigation, Nat. Hazards, 4, 301-316, 1991.

Fliri, F.: Naturchronik von Tirol, Universitätsverlag Wagner, Innsbruck, 1998.

Flores, T.: Las invasiones bruscas del mar a los litorales Mexicanos, Annales de la Commission paur L'etude des Raz de Maree, 4, 94-99, 1934.

Fréchet, J., Meghraoui, M., and Stucchi, M. (Eds.): Historical seismology: interdisciplinary studies of past and recent earthquakes, Modern approaches in solid earth sciences, Springer-Verlag New York Inc., United States, 2008.

Gaspar, P.: The day when the sea went out, interview, conducted by Corona, N.: March 10, 2010, in Cuyutlán, Colima, 2010.

Gianfreda, F., Mastronuzzi, G., and Sansò, P.: Impact of historical tsunamis on a sandy coastal barrier: an example from the northern Gargano coast, southern Italy, Nat. Hazards Earth Syst. Sci., 1, 213-219, doi:10.5194/nhess-1-213-2001, 2001.

Gianluca, L.: La Inundación de Vajont: Representaciones periodísticas de un desastre italiano, Desacatos, 19, 71-84, 2005.

Glade, T., Albini, P., and Frances, F. (Eds): The use of historical data in natural hazards assessment, Kluwer Academic Publishers, The Netherlands, 2001.

Goff, J.: Evidence of a previously unrecorded local tsunami, 13 April 2010, Cook Islands: implications for Pacific Island countries, Nat. Hazards Earth Syst. Sci., 11, 1371-1379, doi:10.5194/nhess-11-1371-2011, 2011.

Goff, J. R., Hicks, M. D., and Hurren, H.: Tsunami geomorphology in New Zealand: a new method for exploring the evidence of past tsunamis, NIWA technical report No. 18, Wellington, 69 pp., 2007.

Goff, J. R., McFadgen, B., Wells, A., and Hicks, M.: Seismic signal in coastal dune systems, Earth-Sci. Rev., 89, 73-77, doi:10.1016/j.earscirev.2008.03.002, 2008.

Goff, J. R., Lane, E., and Arnold, J.: The tsunami geomorphology of coastal dunes, Nat. Hazards Earth Syst. Sci., 9, 847-854, doi:10.5194/nhess-9-847-2009, 2009.

Gregory, I. and Ell, P.: Historical GIS: Technologies, Methodologies and Scholarship, Cambridge University Press, New York, 2007.

Guidoboni, E.: Vesuvius: A historical approach to the 1631 eruption "cold data" from the analysis of three contemporary treatises, J. Volcanol. Geotherm. Res., 178, 347-358, doi:10.1016/j.jvolgeores.2008.09.020, 2008.

Hernández, F.: El Colima de Ayer, 4th. Ed., Universidad de Colima, Colima, 2009. 
Historical Tsunami Database for the World Ocean (HTDB/WLD): available at: http://tsun.sscc.ru/nh/tsunami.php, last access: 10 August 2011.

Instituto Nacional de Geografía, Estadística e Informática (INEGI): available at: http://www.inegi.org.mx/lib/Olap/consulta/, last access: 10 December 2010.

Kanamori, H.: Lessons from the 2004 Sumatra-Andaman earthquake, Phil. Trans. R. Soc. A., 364, 1927-1945, doi:10.1098/rsta.2006.1806, 2006.

Kates, R. W., Colten, C. E., Laska, S., and Leatherman, S. P.: Reconstruction of New Orleans after Hurricane Katrina: A research perspective, P. Natl. Acad. Sci. USA, 103, 14653-14660, doi:10.1073/pnas.0605726103, 2006.

Kovalerchuk, B.: Visual Correlation Methods and Models, in: Visual and Spatial Analysis: Advances in Data Mining, Reasoning, and problem Solving, edited by: Kovalerchuk, B. and Schwing, J., Springer, Netherlands, 175-207, 2004.

Lagos, M. and Cisternas, M.: El Nuevo Riesgo de Tsunami Considerando el Peor Escenario en Actas del X Coloquio Internacional de Geografía: Diez años de cambios en el mundo, en la geografía y en las ciencias sociales, 1999-2008, Barcelona, 2008.

Levin, B. and Nosov, M.: Physics of Tsunamis, Springer, 2009.

Liseikin, V. D.: Grid Generation Methods, 2, Springer, Russia, 2010.

Llasat, M.-C., Barriendos, M., Barrera, A., and Rigo, T.: Floods in Catalonia (NE Spain) since the 14th century. Climatological and meteorological aspects from historical documentary sources and old instrumental records, J. Hydrol., 313, 32-47, doi:10.1016/j.jhydrol.2005.02.004, 2005.

Lübken, U. and Mauch, Ch.: Uncertain Environments: Natural Hazards, Risk and Insurance, in: Historical Perspective, Environment and History, 17, 1-12, doi:10.3197/096734011X12922358301012, 2011.

Luhr, J., Nelson, S., Allan, J., and Carmichael, I.: Active rifting in southwestern Mexico: Manifestations of an incipient eastward spreading-ridge jump, Geology, 13, 54-57, doi:10.1130/00917613(1985)13<54:ARISMM>2.0.CO;2, 1985.

MAR V0.9 2010: Gonzalez J. I., CICESE, Ensenada, Mexico, computer program, 2010.

Mimura, N., Yasuhara, K., Kawagoe, S., Yokoki, H., and Kazama, S.: Damage from the Great East Japan Earthquake and Tsunami - A quick report, Mitig. Adapt. Strategies Glob. Chang., 16, 803818, doi:10.1007/s11027-011-9297-7, 2011.

Mojarro, V.: The day when the sea went out, interview, conducted by Corona, N.: April, 13, 2010, in Cuyutlán, Colima, 2010.

Murchison, J. M.: Ethnography Essentials: Designing, conducting, and presenting your research, Jossey-Bass, San Francisco, United States of America, 2010.

National Geodata Base Center, Historical Tsunami Database (NGDC): available at: http://www.ngdc.noaa.gov/hazard/tsu_db. shtml, Access: 8 June 2011.

Naulet, R., Lang, M., Coeur, D., and Gigon, C.: Collaboration between historians and hydrologists on the Ardeche River (France), in: The Use of Historical Data in Natural Hazard Assessments, edited by: Glade, T., Albini, P., and Frances, F., Kluwer Academic Publishers, The Netherlands, 113-129, 2001.

Nixon, G. T.: The relationship between quaternary volcanism in central Mexico and the seismicity and the structure of sub- ducted ocean lithosphere, Geol. Soc. Am. Bull., 93, 514-523, doi:10.1130/0016-7606(1982)93<514:TRBQVI>2.0.CO;2, 1982.

Nott, J.: Extremely high-energy wave deposits inside the Great Barrier Reef, Australia: Determining the cause, - tsunami or tropical cyclone?, Mar. Geol., 141, 193-207, doi:10.1016/S00253227(97)00063-7, 1997.

Okal, E. A. and Borrero, J. C.: The tsunami earthquake of 1932 June 22 in Manzanillo, México: seismological study and tsunami simulations, Geophys. J. Int., 187, 1-17, doi:10.1111/j.1365246X.2011.05199.x, 2011.

Ordóñez, E.: Seismic Activity in Mexico during June, 1932, B. Seismol. Soc. Am., 23, 80-82, 1933.

Orfanogiannaki, K. and Papadopoulos, G. A.: Conditional probability approach of the assessment of tsunami potential: Application in three tsunamigenic regions of the Pacific Ocean, Pure Appl. Geophys., 164, 593-603, doi:10.1007/s00024-006-01707, 2007.

O'Sullivan, D. and Unwin, D.: Geographic Information Analysis, John Wiley \& Sons, New Jersey, 2003.

Oseguera, J.: Colima en panorama: Monografía histórica, geográfica, política y sociológica, S.P.I., Colima, 1967.

Papadopoulos, G. A. and Imamura, F.: A proposal for a new tsunami intensity scale, ITS, Seattle, 569-577, 2001.

Pedersen, G.: Modeling Runup with Depth Integrated Equation Models, in: Advances numerical models for simulating tsunami waves and runup, edited by: Liu, P. L. F., Yeh, H., and Synolakis, C., World Scientific Publishing Co. Pte. Ltd., Singapore, 3-42, 2008.

Pelinovsky, E., Kharif, C., Riabov, I., and Francius, M.: Study of tsunami propagation in the Ligurian Sea, Nat. Hazards Earth Syst. Sci., 1, 195-201, doi:10.5194/nhess-1-195-2001, 2001.

Pfister, C.: Wetternachhersage, 500 Jahre Klimavarioationen und Naturkatastrophen, Haupt, Bern, 1999.

Ramírez-Herrera, M. T., Kostoglodov, V., Summerfield, M., Urrutia-Fucugauchi, J., and Zamorano-Orozco, J.: A reconnaissance study of the morphotectonics of the Mexican subduction zone, Z. Geomorphol., 118, 207-226, 1999.

Ramírez-Herrera, M. T., Kostoglodov, V., and Urrutia-Fucugauchi, J.: Overview of Recent Coastal Tectonic Deformation in the Mexican Subduction Zone, Pure Appl. Geophys., 168, 14151433, doi:10.1007/s00024-010-0205-y, 2011.

Reyes, J. C.: Sal, el oro blanco de Colima, México, Gobierno del Estado de Colima/Secretaría de Cultura, Colima, 36-40, 2004.

Ribera, P., Gallego, D., Pena-Ortiz, C., Del Rio, L., Plomaritis, T. A., and Benavente, J.: Reconstruction of Atlantic historical winter coastal storms in the Spanish coasts of the Gulf of Cadiz, 1929-2005, Nat. Hazards Earth Syst. Sci., 11, 17151722, doi:10.5194/nhess-11-1715-2011, 2011.

Salazar, J.: Una Montaña de Agua, Diario de Colima, p. 2, p. 3, June 30, 1985, 1985.

Salazar, J.: El Maremoto de Cuyutlán, 1932, Investigaciones Históricas 2, Sociedad Colimense de Estudios Históricos, Colima, México, 1989.

Sánchez, A. J. and Farreras, S. F.: Catalog of tsunamis on the Western Coast of México, World Data Center A for Solid Earth Geophysics, Boulder: National Geophysical Data Center/NOAA, 1993. 
Satake, K. and Atwater, B.: Long-term perspectives on giant earthquakes and tsunamis at subduction zones, Annu. Rev. Earth Pl. Sc., 35, 349-374, doi:10.1146/annurev.earth.35.031306.140302, 2007.

Secor, A. J.: Social surveys, interviews, and focus groups, in: Research methods in geography: a critical Introduction, edited by: Gomez, B. and Jones III, J. P., Wiley-Blackwell, Singapore, 194205, 2010.

Seidel, J., Imbery, F., Dostal, P., Sudhaus, D., and Bürger, K.: Potential of historical meteorological and hydrological data for the reconstruction of historical flood events - the example of the 1882 flood in southwest Germany, Nat. Hazards Earth Syst. Sci., 9, 175-183, doi:10.5194/nhess-9-175-2009, 2009.

Servicio Sismológico Nacional (SSN): available at: http://www.ssn. unam.mx, last access: 2 November 2010.

Sigurdsson, H., Carey, S., Cornell, W., and Pescatore, T.: The eruption of Vesuvius in A.D. 79, Natl. Geogr. Res., 1, 332-387, 1985.

Singh, S. K., Asitz, L., and Havskov, J.: Seismic gaps and recurrence periods of large earthquakes along the Mexican Subduction Zone: A reexamination, B. Seismol. Soc. Am., 71, 827-843, 1981.

Singh, S. K., Ponce, J., and Nishenko, S. P.: The great Jalisco, Mexico, earthquakes of 1932: subduction of the Rivera Plate, B. Seismol. Soc. Am., 75, 1301-1313, 1985.

Singh S. K., Pacheco, J., and Shapiro, N. M.: the earthquake of 16 november, $1925(\mathrm{Ms}=7.0)$ and the Reported tsunami in Zihuatenejo, Mexico, Geofís. Int., 37, 49-52, 1998.

Soloviev, S. L. and Go, Ch. N.: Catalogue of tsunamis on the eastern shore of the Pacific Ocean, Canadian Translation of Fisheries and Aquatic Sciences, Ottawa, 1984.

Stein, S.: Limitations of a young science, Seismol. Res. Lett., 77, 351-353, 2006.

Stein, S. and Okal, E. A.: Ultralong period seismic study of the December 2004 Indian Ocean earthquake and implications for the regional tectonics and the subduction process, B. Seismol. Soc. Am., 97, 279-295, doi:10.1785/0120050617, 2007.
Strunz, G., Post, J., Zosseder, K., Wegscheider, S., Mück, M., Riedlinger, T., Mehl, H., Dech, S., Birkmann, J., Gebert, N., Harjono, H., Anwar, H. Z., Sumaryono, Khomarudin, R. M., and Muhari, A.: Tsunami risk assessment in Indonesia, Nat. Hazards Earth Syst. Sci., 11, 67-82, doi:10.5194/nhess-11-67-2011, 2011.

Titov, V. V. and Synolakis, C. E.: Extreme inundation flows during the Hokkaido-Nansei-Oki Tsunami, Geophys. Res. Lett., 24, 1315-1318, doi:10.1029/97GL01128, 1997.

UNESCO-IOC: Tsunami Glossary, IOC information document, 1221, UNESCO, Paris, 2006.

Walliman, N.: Social Research Methods, GAGE Publications, London, 2006.

Walsh, T. J., Titov, V. V., Venturato, A. J., Mofjeld, H. O., and Gonzalez, F. I.: Tsunami Hazard Map of the Elliott Bay Area, Seattle,Washington: Modeled Tsunami Inundation from a Seattle Fault Earthquake, Washington division of geology and earth resources, Seattle, Washington, open file report 2003-14, 2003.

Wagner, K. and Suda, M.: Natural hazards in the perspective of the public: A big black box, Internationales Symposion zum Schutz des Lebensraumes vor Hochwasser, Muren, Lawinen und Hangbewegungen, 4 (IX), 285-296, 2004.

Wang, P. and Zhang, D.: An introduction to some historical governmental weather records of China, B. Am. Meteorol. Soc., 69, 753-758, doi:10.1175/15200477(1988)069<0753:AITSHG > 2.0.CO;2, 1988.

Yanagisawa, K., Imamura, F., Sakakiyama, T., Annaka, T., Takeda, T., and Shuto, N.: Tsunami assessment for risk management at nuclear power facilities in Japan, Pure Appl. Geophys., 164, 565-576, doi:10.1007/s00024-006-0176-1, 2007.

Zhan, C., Menon, S., and Gao, P.: A directional path distance model for raster distance mapping, Lect. Notes Comput. Sc., 716, 434443, doi:10.1007/3-540-57207-429, 1993. 